\title{
Natural Field Spread of Mild and Severe Isolates of Citrus Tristeza Virus in Florida
}

\author{
C. A. Powell, R. R. Pelosi, and R. C. Bullock, University of Florida, IFAS, Indian River Research and Education \\ Center, 2199 South Rock Road, Fort Pierce 34045-3138
}

\begin{abstract}
Powell, C. A., Pelosi, R. R., and Bullock, R. C. 1997. Natural field spread of mild and severe isolates of citrus tristeza virus in Florida. Plant Dis. 81:18-20.

The effectiveness of five different aphid control regimes in delaying movement of mild and severe isolates of citrus tristeza virus (CTV) into a CTV-free sweet orange scion on sour orange rootstock block was monitored annually for 5 years, using severe isolate-specific and isolatenonspecific monoclonal antibodies. The average percentage of trees infected with a severe isolate of CTV was 32, 32, 20, 25, and 28 for trees treated with Temik, Temik + Meta-Systox R (MSR), MSR, stylet oil, or no aphid control, respectively, at the conclusion of the experiment (5 years). These percentages were not significantly different $(P \leq 0.05)$. The average percentage of trees infected only with mild isolates was $13,10,7,7$, and 17 for the above treatments, respectively. The infection with mild isolates was significantly greater $(P \leq 0.05)$ with no aphid control than with stylet oil or MSR treatments.
\end{abstract}

Citrus tristeza virus (CTV) causes tree decline and death worldwide wherever citrus is grown predominantly on sour orange rootstock $(1,3)$. The virus is not a single entity but a family of related viruses that can cause a variety of symptoms depending on the host and environmental conditions (2,7). Different isolates of the virus can induce stem-pitting of the grapefruit or sweet orange scion irrespective of the rootstock, a variety of decline symptoms in sweet orange or grapefruit on sour orange rootstock, or no symptoms. Comparison of nucleic acid sequence among a limited number of CTV isolates indicates that isolates differ by as much as $35 \%$ in some open reading frames (A. Karasev, unpublished). The symptomology of CTVinduced disease may be further complicated by isolate mixtures in trees and the presence of defective interfering particles (8). In Florida, only sour orange decline and symptomless strains are commonly found in commercial citrus. Stem-pitting isolates are present in the state but apparently are confined to homeowner and lemon plantings and have not been readily transmitted by aphid vectors currently

Corresponding author: C. A. Powell

E-mail: capo@gnv.ifas.ufl.edu

Florida Agricultural Experiment Station Journal Series R-04989.

Accepted for publication 17 September 1996.

Publication no. D-1996-1028-08R

This article is in the public domain and not copyrightable. It may be freely reprinted with customary crediting of the source. The American Phytopathological Society, 1997. common in Florida (S. M. Garnsey, R. F. Lee, R. K. Yokomi, and C. A. Powell, unpublished).

The primary vectors of CTV are the brown citrus aphid, Toxoptera citricidus (Kirkaldy) (6), the melon aphid, Aphis gossypii Glover, and the green citrus aphid, Aphis spiraecola Patch (7); the latter two are currently responsible for the majority of CTV transmission in Florida. Only recently has the brown citrus aphid been introduced into Florida. The rate of transmission and field spread of CTV has been examined in California $(13,14)$, Spain (4), and Florida $(16,17)$. These studies have indicated that there are both highly and poorly transmissible CTV isolates. However, little information is available on the relative rates of spread of decline-inducing and symptomless isolates in Florida.

Monoclonal antibodies can distinguish most decline and stem-pitting isolates of CTV from symptomless isolates $(5,10)$. These antibodies have been useful for strain differentiation in field epidemiological studies $(11,12)$. We have used these antibodies to monitor the spread of decline-inducing and symptomless isolates of CTV in field citrus with several aphid control measures.

\section{MATERIALS AND METHODS}

Three hundred Hamlin sweet orange (Citrus sinensis (L.) Osbeck) trees grafted onto sour orange rootstock (C. aurantium L.) were planted in May 1989 adjacent to a Temple orange block that was virtually $100 \%$ infected with mild and severe isolates of CTV. The test trees were in double beds with $6.1 \mathrm{~m}$ between rows in the same bed and $9.15 \mathrm{~m}$ between rows in different beds. The between-tree spacing was $4.6 \mathrm{~m}$.
The experimental design was a randomized complete block with 2 rows on the same bed serving as a replication. There were five treatments in each of six replications; each treatment contained 10 trees, 5 trees in one row and 5 trees in the adjacent row in the same bed. The treatments were annual applications of Temik (RhonePoulenc, Research Triangle Park, NC) (8.5 $\mathrm{g}$ of active ingredient per tree, incorporated into the soil), Meta-Systox-R (Mobay Corp., Kansas City, MO) (foliar spray, 0.62 $\mathrm{ml}$ per liter), a combination of the first two treatments, JMS stylet oil emulsion (JMS Flower Farms, Inc., Vero Beach, FL) (foliar spray, $43.4 \mathrm{ml}$ per liter of a $0.75 \%$ solution), and no application. Temik was applied during the winter between 10 January and 14 February, and the foliar sprays were applied in the spring between 19 April and 22 May. Young flush was sampled at three locations on each tree during the winters of 1990 through 1994. The three samples were combined and bark from the freshly collected tissue was finely chopped with a razor blade, triturated with a Tissumizer (Tekmar, Cincinnati, OH), and analyzed for mild and severe isolates of CTV by indirect double-antibody sandwich enzyme-linked immunosorbent assay (ELISA) as previously described (12), except that the monoclonal antibody $17 \mathrm{G} 11$ (15) was used instead of 3DF1 (15). Data (percentages) were subjected to analysis of variance, and treatment means were separated by Duncan's multiple range test at $P$ $\leq 0.05$.

At the conclusion of the experiment each tree was given a rating on a scale of 0 , 1,2 , or 3 for no symptoms, slight decline, moderate decline, or severe decline, respectively. Trees with slight decline had visible thinning of the canopy, trees with moderate decline had a visual canopy density reduction of 25 to $50 \%$, and trees with severe decline had a visual canopy density reduction of greater than $50 \%$. In addition, the trunk circumference of each tree was measured $10 \mathrm{~cm}$ above the graft union. Numbers and species of winged aphids were monitored weekly with both yellow sticky traps (Trece, Inc., Salinas, CA) and yellow pans (water traps) (9).

\section{RESULTS}

The percentage of untreated trees infected with CTV after one, two, three, four, or five growing seasons was 0.0, 2, 19, 20, and 45 , respectively. There was no signifi- 
cant difference among the treatments with regard to infection with severe isolates of CTV during any year $(P \leq 0.05)$ (Table 1$)$. Meta-Systox-R or stylet oil treatments appeared to reduce mild isolate infection after five growing seasons. The distribution of infected trees in the plot was random with no clustering or increased infection of trees nearest the neighboring infected Temple orange block.

After 5 years, the percentage of trees infected with severe isolates $(27 \%, 81$ of $300)$ was greater than that of those infected with only mild isolates $(11 \%, 33$ of 300$)$. The infection with mild isolates is probably an underestimate since doubly infected trees would be scored as severe (the antibodies cannot distinguish a tree that contains only a severe isolate from one that contains a mixture of severe and mild isolates). However, since $15 \%$ (33 of 219) of the trees without a severe isolate contained a mild isolate, it is likely that only $15 \%$ (12 of 81) of the trees with a severe isolate are doubly infected with a mild isolate (assuming no cross-protection). If the number of known mild-isolate-infected trees (33) is added to the assumed number of severe-isolate-containing trees that are also infected with a mild isolate (12), there compared to 45 ) infected with severe isolates as infected with mild isolates after 5 years. Whether the faster movement of severe strains is due to vector efficiency, inoculum levels, or both is not known, but it would help explain why any naturally occurring mild, cross-protecting isolates of would still be 1.8 times as many trees ( 81

CTV may not be able to infect CTV-free trees in time to protect them from severe isolates.

The average tree condition after 5 years (rated 0 to 3 , with $0=$ no symptoms and 3 $=$ severe decline) for trees treated with Temik, Temik + Meta-Systox-R, MetaSystox-R, stylet oil, or no application was $0.62,0.96,0.84,0.75$, and 0.81 , respectively. These numbers are not significantly different $(P \leq 0.05)$. The average tree circumference for each of the above five treatments was 12.0, 12.0, 12.8, 12.9, and $13.0 \mathrm{~cm}$, respectively. These averages, which include measurements from uninfected, mild-isolate-infected, and severeisolate-infected trees, are not significantly different $(P \leq 0.05)$. These data indicate that none of the aphid control procedures effectively improved tree quality.

Winged aphid species found in water traps and yellow sticky traps included Aphis spiraecola Patch, Macrosiphum euphorbiae (Thomas), Toxoptera aurantii (Boyer de Fonscolombe), Aphis craccivora Koch, Aphis gossypii Glover, Myzus persicae Sulzer, and aphids that could not be identified due to poor condition or that were known not to colonize citrus.

The total number of CTV vector aphids collected per year in the water traps plus the yellow sticky pans is shown in Table 2 . Aphid flights varied considerably among years. This was especially apparent with $A$. spiraecola: traps contained more than three times as many aphids in 1993 as in other years. A. gossypii flights were also heavy in 1990 and 1993. The heavy 1993 flights

Table 1. Spread of severe and mild isolates of citrus tristeza virus (CTV) under natural conditions over a 5-year period

\begin{tabular}{|c|c|c|c|c|c|c|c|c|c|c|}
\hline \multirow[b]{3}{*}{ Aphid control } & \multicolumn{10}{|c|}{ CTV infection $(\%)^{\mathrm{w}}$} \\
\hline & \multicolumn{2}{|c|}{1990} & \multicolumn{2}{|c|}{1991} & \multicolumn{2}{|c|}{1992} & \multicolumn{2}{|c|}{1993} & \multicolumn{2}{|c|}{1994} \\
\hline & Severe $^{\mathrm{x}}$ & Mild $^{y}$ & Severe $^{x}$ & Mild $^{y}$ & Severe $^{\mathrm{x}}$ & Mild $^{y}$ & Severe $^{\mathrm{x}}$ & Mild $^{y}$ & Severe $^{x}$ & Mildy \\
\hline Temik & 0 & 0 & 0 & 0 & 10 & $3 \mathrm{a}$ & 10 & $5 \mathrm{a}$ & 32 & $13 \mathrm{ab}$ \\
\hline Temik + MSR ${ }^{z}$ & 0 & 0 & 0 & 0 & 3 & $3 \mathrm{a}$ & 5 & $3 \mathrm{a}$ & 32 & $10 \mathrm{ab}$ \\
\hline $\mathrm{MSR}^{\mathrm{z}}$ & 0 & 0 & 0 & 0 & 3 & $8 \mathrm{ab}$ & 3 & $8 \mathrm{ab}$ & 20 & $7 \mathrm{a}$ \\
\hline Stylet oil & 0 & 0 & 0 & 2 & 8 & $2 \mathrm{a}$ & 8 & $7 \mathrm{ab}$ & 25 & $7 \mathrm{a}$ \\
\hline None & 0 & 0 & 0 & 2 & 7 & $12 \mathrm{~b}$ & 7 & $13 \mathrm{~b}$ & 28 & $17 \mathrm{~b}$ \\
\hline
\end{tabular}

${ }^{\mathrm{w}}$ Average of six replications with 10 trees per replication. Based on enzyme-linked immunosorbent assay with monoclonal antibodies that can differentiate mild and severe isolates. Means separation by Duncan's multiple range test, $5 \%$ level.

${ }^{x}$ Sap from leaves reacted with MAbs 1D3 + MCA13.

${ }^{y}$ Sap from leaves reacted with MAb 17G11, but not 1D3 + MCA13.

${ }^{\mathrm{z}}$ Meta Systox-R.

Table 2. Total number of Aphis spiraecola and A. gossypii and percentage of trees diagnosed with citrus tristeza virus (CTV) in Hamlin oranges 1990 through 1994

\begin{tabular}{lcccc}
\hline Collection year & $\begin{array}{c}\text { A. gossypii } \\
(\text { no. })^{\mathbf{y}}\end{array}$ & $\begin{array}{c}\text { A. spiraecola } \\
(\text { no. })^{\mathbf{y}}\end{array}$ & $\begin{array}{c}\text { CTV sample } \\
\text { year }\end{array}$ & $\begin{array}{c}\text { CTV in untreated } \\
\text { trees }(\%)\end{array}$ \\
\hline $1989^{z}$ & 72 & 48 & 1990 & 0 \\
1990 & 432 & 689 & 1991 & 2 \\
1991 & 225 & 424 & 1992 & 19 \\
1992 & 141 & 320 & 1993 & 20 \\
1993 & 244 & 2594 & 1994 & 45 \\
\hline
\end{tabular}

${ }^{\mathrm{y}}$ Total number of aphids collected in water traps and yellow sticky traps.

${ }^{\mathrm{z}}$ Aphids collected for only 7 months (June through December). may be correlated with the increased CTV infection in 1994. Aphid flights were normally heaviest in November and December, but some years they were also heavy in March and April. Details on aphid flight patterns over the 5-year period will be published elsewhere.

\section{DISCUSSION}

Movement of CTV into the CTV-free block was relatively slow (38\% of trees infected after 5 years). This is probably due to the low efficiency of CTV transmission by $A$. gossypii and A. spiraecola (16). The slow movement of CTV was not due to a paucity of inoculum, since a Temple sweet orange grove adjacent to the experimental block was virtually $100 \%$ infected with both mild and severe isolates of CTV. The percentages of infection reported here are similar to those reported in crossprotected trees at a nearby location (12). Although the efficiency of transmission may be low, large single-year increases in CTV infection can occur (Table 2, between 1993 and 1994) when large numbers of aphids are present.

There was good correlation between positive ELISA reactions for severe CTV and tree decline. It took about 3 years for a tree that tested positive by ELISA to show severe decline symptoms. Some of the trees that tested positive by ELISA for severe CTV the final year did not yet show decline symptoms. There were no severe drought conditions during the course of the experiment. Previous field observations indicate drought can hasten CTV-induced decline.

None of the treatments designed to reduce aphid populations were effective in controlling CTV-induced disease. This is documented by the percentage of severe isolate infection (Table 1), tree decline rating, and trunk circumference measurements. Thus, aphid control currently may not be a viable control for CTV in Florida. This could change when the more efficient vector $T$. citricidus becomes prevalent.

\section{ACKNOWLEDGMENTS}

We thank Jack Cordy and Ed Killer for technical assistance. This project was funded in part by USDA Special Cooperative Agreement No. 586617-4-018. We also thank U.S. Sugar Corporation for donating the trees used in the experiment, and Rhone-Poulenc, Mobay Corp., and JMS Florida Flower Farms, Inc., for donating the chemicals applied to control aphids.

\section{LITERATURE CITED}

1. Bar-Joseph, M., Roistacher, C. N., Garnsey, S. M., and Gumpf, D. J. 1981. A review on tristeza, an ongoing threat to citriculture. Proc. Int. Soc. Citric. 1:419-422.

2. Garnsey, S. M., Gumpf, D. J., Roistacher, C. N., Civerolo, E. L., Lee, R. F., Yokomi, R. K. and Bar-Joseph, M. 1987. Toward a standardized evaluation of the biological properties of citrus tristeza virus. Phytophylactica 19:151-157.

3. Garnsey, S. M., and Lee, R. F. 1988. Tristeza. Pages 48-50 in: Compendium of Citrus Diseases. J. O. Whiteside, S. M. Garnsey, and L. 
W. Timmer, eds. American Phytopathological Society, St. Paul, MN.

4. Hermoso de Mendosa, A., Ballester-Olmos, J. F., Pina, J., Sera, J. A., and Fuertes, C. 1988. Difference in transmission efficiency of citrus tristeza virus by Aphis gossypii using sweet orange, mandarin, or lemon trees as donor or receptor host plants. Pages 62-64 in: Proc. Conf. Int. Organ. Citrus Virol., 10th. IOCV, Riverside, CA.

5. Hooker, M. E., Powell, C. A., Lee, R. F., Brlansky, R. H., and Garnsey, S. H. 1993. Development of monoclonal antibodies to citrus tristeza virus. (Abstr.) Phytopathology 83: 1378-1379.

6. Meneghini, M. 1946. Sobre a natureza e transmissibilidade do doencia "tristeza" dos citrus. O Biologica 12:285-287.

7. Miyakawa, T. 1987. Strains of citrus tristeza virus in Japan. Phytophylactica 19:134-144.

8. Munir, M., Karasev, A. V., Mietkiewska, E., Gafny, R., Lee, R. F., Dawson, W. O., and
Bar-Joseph, M. 1995. Defective RNA molecules associated with citrus tristeza virus. Virology 208:383-387.

9. Nielsson, R. J., and Wolfenbarger, D. O. 1970. Collections of winged aphids in yellow pans in south Florida. Fla. Entomol. 53:249-250.

10. Permar, T. A., Garnsey, S. M., Gumpf, D. J., and Lee, R. F. 1990. A monoclonal antibody that discriminates strains of citrus tristeza virus. Phytopathology 80:224-228.

11. Powell, C. A., and Pelosi, R. R. 1993. Prevalence of severe strains of citrus tristeza virus in Florida citrus nurseries. HortScience 28: 699-700.

12. Powell, C. A., Pelosi, R. R., and Cohen, M. 1992. Superinfection of orange trees containing mild isolates of citrus tristeza virus with severe Florida isolates of citrus tristeza virus. Plant Dis. 76:141-144.

13. Roistacher, C. N., Bar-Joseph, M., and Gumpf, D. J. 1984. Transmission of tristeza and seedling yellows tristeza virus by small populations of Aphis gossypii. Plant Dis. 68: 494-496.

14. Roistacher, C. N., Nauer, E. M., Kishaba, A., and Calavan, E. C. 1980. Transmission of citrus tristeza virus by Aphis gossypii reflecting changes in virus transmissibility in California Pages 76-82 in: Proc. Conf. Int. Organ. Citrus Virol., 8th. IOCV, Riverside, CA.

15. Vela, C., Cambra, M., Cortes, E., Moreno, P. Miguet, J. G., Perez de san Roman, C., and Sanz, A. 1986. Production and characterization of monoclonal antibodies specific for citrus tristeza virus and their use in diagnosis. $\mathrm{J}$. Gen. Virol. 67:91-96.

16. Yokomi, R. K., and Garnsey, S. M. 1987. Transmission of citrus tristeza virus by Aphis gossypii and Aphis citricola in Florida. Phytophylactica 19:169-172.

17. Yokomi, R. K., Garnsey, S. M., Lee, R. F., and Cohen, M. 1987. Use of vectors for screening protecting effects of mild citrus tristeza virus isolates in Florida. Phytophylactica 19:183185. 